\title{
Robin Hyde (Iris Wilkinson), \\ 1906-1939
}

\author{
Mary Edmond-Paul
}

Robin Hyde, poet, novelist, journalist, is now acknowledged as a major figure in New Zealand twentieth-century culture, although the literary nationalist group that became prominent in New Zealand in the late thirties and early forties temporarily eclipsed her reputation. Hyde had an immensely productive short life but the self-doubt and anxiety that had plagued her were exacerbated by the social isolation of London and she committed suicide there at the age of thirty-three. During her lifetime Hyde was well-known as an outspoken journalist and literary commentator as well as poet and novelist; her intelligence as a writer, the stylistic interest and beauty of her work, and her ability to encapsulate and comment on contemporary society have only been fully understood as her novels have been brought back into print, her autobiographical writings discovered, and unpublished papers-including poems, letters and short fiction-further studied in the context of her life. These new discoveries reveal her as a female modernist, even in some respects a New Zealand Frida Kahlo figure, whose physical suffering and experience of gender politics in personal and professional life gave her work a special resonance; and because Hyde's writing drew so much on her own experience, it is of particular importance to understand her literary and personal history together.

Hyde was born Iris Wilkinson in Cape Town on the nineteenth of January 1906. Her family history reveals a complex engagement in imperial projectswar, communications, and colonial administration-that characterised a significant part of the movement of population to New Zealand and other Commonwealth countries at the beginning of the twentieth century. Her father, George Edward was born in Agra, where his father (originally from Yorkshire) had a successful career in the Indian Civil Service. At eighteen years old he joined an Anglo-Indian corps to fight in the Boer War. After the war hospitalised with war wounds, his wife-to-be, a twenty-nine-year-old Australian, working in South Africa en route to England, nursed him. Unsure as to employment, George finally settled with the post and telegraph service and when Adelaide (Nelly) née Butler fell pregnant they married. Following the birth of their second daughter, Iris, the family sailed for New Zealand, perhaps assuming that country would also need young men with experience in 
communications systems; but prospects for advancement in the years of war and Depression that followed proved slim.

Soon after their arrival in Wellington, New Zealand George got a position, as a sorter and clerical worker in the Post and Telegraph Department, where he remained (apart from service overseas during the First World war) for the thirty-four years of his working life. Iris was the second of four daughters, the third and fourth were born in New Zealand, and their mother maintained a constant vigilance over their appearance and manners to ensure they grew up proper middle-class girls, notwithstanding the working-class suburbs in which their father's low income and health (a war wound to his leg meant that cycling from a more salubrious hill suburb was too tiring) obliged them to live. But George Wilkinson's socialist and questioning attitudes were very different from those of his wife. He brought home books and loved discussion about politics as well as philosophy and literature. What irritated George's wife gave his daughter Iris an interest in acquiring a broad and international perspective on society and the world-visible not only in her novels but also from early on in her journalistic writing.

Iris Wilkinson was talented at school in all subjects-except for mathematics - and her love of poetry and recitation was already noted by the time she was seven years old when the teacher allowed her to read her own poems out to the class-poems that were apparently on fanciful and imaginative subjects such as moon and stars, fairies and elves. In the biofictional novel, The Godwits Fly, Hyde recounts a formative adventure when on a summer evening visit to a Wellington beach (Island Bay) she went missing and was found curled up, alone in a little fishing dinghy composing verses. The adventure culminates in a furious mother, only mollified by the quality of her daughter's verses, presenting Iris with an exercise book for her future compositions

Iris was an intelligent child who desired to heal rifts in her parent's marriage by giving dignity and status to her much criticised father. This matches the portrait of an imaginative and intelligent but over-sensitive child that Hyde later drew of Eliza in Godwits. Hyde also later commented both in an (unpublished) essay on mental health and in her autobiographical writing on the mental injuries sustained by children in situations of family conflict-and this also became a theme in a number of her novels. George spent two years overseas during the war; but though his family believed that he was initially in action at Salonika, war records show he served only in the United Kingdomwith the Postal Service of the New Zealand Engineers.

The imagery and anecdotes of empire and war provided inspiration for Iris's early writing, as did bible stories and prayers. During the summer holidays of 1916 she participated in a contest to compose the best prayer for the 
children's mission hour; Iris wrote several entries and distributed some to other children. When one of the latter was the winner, the prize-winner burst into tears and confessed that Iris had written it. Iris also continued to enjoy delivering dramatic renderings of her own and others' poems with which she recalls terrifying her sisters. The local church minister described her as a: 'small chubby child with a quick brain . . . a reciter . . . much to the fore at Sunday school concerts' who would 'deliver her lines with unclouded confidence and surprising vigour, every part of her body contributing to the general effect' (Challis/Rawlinson, 751 ).

George returned from war in 1918 and his soldier's gratuity enabled the Wilkinsons to buy their own home-to move from the working-class areas of Newtown and Berhampore to the respectability of a large house and garden in the suburb of Northland. Iris, as the family scholar, was privileged with an upstairs bedroom of her own, next to a balcony. Nelly now determined that regardless of cost all her daughters should have a secondary education. In 1919 Iris began at Wellington Girls' College where she almost immediately made her first close friend and published a prize-winning short story and poems in the school magazine. By dint of her writing talents she avoided some of the inevitable unpopularity that went with being too bookish, and no good at sports. Her best friend, Gwen Hawthorn, was, like Iris, ambitious of life and experience, wanting to be a painter; the two of them had pretensions to sophistication that set them apart from their schoolmates. In her poems Iris was already using the Arthurian characters and themes that were to be of continuous interest to her, and while still at school she began sending poems (unsuccessfully at first) to New Zealand and Australian journals, Triad, Free Lance and The Bulletin.

In 1921 Iris was awarded a scholarship that would have enabled her to attend university but failing mathematics meant she could not matriculate (graduate), and although she did eventually pass her exams she never used this scholarship. Her last year at school was also the year she met Harry Sweetman, the young man she always considered her soul mate. Harry worked with her father at Post and Telegraph, where they discussed books, and aspired to travel and be a writer. In April 1922 George brought him home to meet his poet daughter; the two got on so well that the next day Harry appeared improbably at her school wanting to give Iris some books and copies of his poems.

The intensity of this relationship was fuelled by Harry's idea of himself as a Jack London figure (he had given up an earlier intention of going to university in favour of the romance of manual labour and being an ordinary bloke and a great lover) and was about to set off working down country near Rangitikei where he was setting up telephone lines. His letters to Iris were composed in 
working men's camps, letters she used later in her characterisation of Timothy in her biofictional novel The Godwits Fly. Iris replied at length-though her letters do not survive. On their next meeting in March 1923 Harry was permitted to stay at the Wilkinson's house. Hyde appears to have seen this relationship as one of the most important of her life-one in which she was truly able to give love-and it was a relationship that continued to be developed, long after his death, in all her writing-most significantly in her poetry. In the same year best friend Gwen moved to a further off suburb, also highlighting the importance of writing in maintaining friendships. An exercise book entitled 'Iris Wilkinson, Wellington Girls' College, Form VI B' is the earliest collection of Hyde's poems still extant.

Under pressure to contribute to the family economy, Iris, on leaving school, applied for a position as a journalist cadet on the local Dominion newspaper and began work there early in 1923 about the time of her seventeenth birthday. Her choice of newspaper, or success in getting the position, may have had something to do with the fact that the Dominion had, in 1921, published an enthusiastic article about her under the heading 'Schoolgirl Poetess.' The experience of working for her first 'hard, but just boss,' C. W. Earle, was to be one of many important mentoring relationships Hyde developed in the newspaper world (Challis/Rawlinson, 44). She was fascinated by the romance of the newspaper traditions: the 'morgue', for example, where the paper kept files of its own and overseas papers that 'went right back into the days of gallantry and esprit'. She wrote about these files later in Journalese. Her salary was an impressive thirty shillings a week, and she was treated with friendly humour by the older men who nick-named her 'Buttercup' or in times of stress, 'Ginger Mick!' The editor encouraged her writing, albeit in a stereotypically gendered move, by making her the inaugural editor of the children's page of the Farmer's Advocate. As Mary Advocate she wrote a letter to the children, answered correspondence and filled the remainder of the page with stories and poems. She also contributed her own zoo stories, in which various animals were interviewed.

In Easter 1924 Iris took a break from her paper to visit Harry Sweetman, now in Auckland, with whom she had a maintained an important and intense correspondence. A moonlight picnic she described later in a letter to his brother as a 'wild affair of grapes and nectarines and madness' was the last time she was to see Harry. In the same week she returned to Wellington she was suddenly bedridden with swelling to her knee; she herself gave differing explanations for this but it seems it was most probably a tubercular infection brought on by an injury. The condition was very serious and involved eight months in hospital where treatment was a painful repeated setting and resetting of the joint under sedation with chloroform and large doses of 
morphine post operatively, resulting in a permanent injury and a long-term reliance on drugs. Initial prognosis that the knee would eventually regain normal function, never eventuated-and the ensuing years saw her often seeking pain relief and comfort from morphine or other sedatives.

The family saw this accident as a turning point in Iris's life, giving her an inferiority complex and making her irritable, but their judgment must have been as difficult to handle as the injury. In the short term her disability gave her a legitimate reason for leaving home and renting her own quarters in town-necessary as she was required to attend late sittings of parliament in her new position as 'Novitia', writing a column entitled 'Peeps at Parliament.' She was employed not as an official parliamentary reporter but as a promising young writer whom the editor hoped might liven up (and perhaps de-politicise) the routine of parliamentary reporting from the Ladies' Gallery; the position though it apparently became wearying gave her name some prominence and introduced her to major figures in New Zealand public life, including Labour member and novelist John A. Lee (who became a close friend) and Prime Minister Coates. 'It does entertain you, when you're only eighteen still, to have tea in state and in private with a Cabinet Minister who loves to hear himself talk to the young and feminine,' she later recalled in Journalese (p. 32). Some of the trials of the column must have come from the instruction by the Dominion, a conservative and anti-Labour paper, to ignore the Labour members who 'provided at least $90 \%$ of the speeches and almost all of the dramatic incidents of the long night watches'. Her response: 'one might as well ask for a snappy scenario about Adam and Eve leaving out any reference to the Serpent' (Journalese, p. 38).

When, improved in health, Iris wrote again to Harry Sweetman, whom she had lost touch with during her illness; she received the news that he was leaving for the kind of overseas adventure they had discussed embarking on together. His departure in October 1925 seems to have been a great shock and disappointment to her-but she also protested that he was expecting her to wait like an Ariadne or Penelope for his return. However, the relationship, with an older member of parliament, Dan Sullivan, may have also had a significant impact. We know that she admired Sullivan, then a senior whip, and that John A. Lee (not always the most reliable source) suggested that there was a love affair. Sullivan, twenty-four years older than her but still with his shock of dark curly hair, looked surprisingly youthful and was liked and respected across the political spectrum for his personal warmth, conciliatory nature, integrity, humanitarian ideals and hard work.'

For whatever reason sometime around Christmas 1925 Iris decided to use an uncle's annuity to take a holiday from Wellington and the newspaper. Rotorua, where further treatment for her knee in the thermal waters was 
prescribed, was the chosen destination, but it was a more glamorous holiday than this suggests. She stayed at a comfortable resort hotel (probably the historic Princes Gate) and took advantage of the opportunity to socialise and wear the new dresses she had bought with her improving salary. She looked so well she felt no one would ever know she 'had been broken and put back together again'. Here she had time to write; several poems, including 'A Daughter to her Mother' and 'Sandcastles' were sent from Rotorua to the Auckland Star but following this Iris did not publish for more than a year.

A young veteran RAF fighter pilot, Frederick de Mulford Hyde, was holidaying at the same hotel with a group of friends. In her own version a nightmare prompted by the roaring of lion from a visiting circus allowed him to comfort her on the very first night at the hotel and he expedited a love affair by moving out of the hotel into a house, where Iris visited him. In a letter to friend Gwen she described the relationship flippantly as 'a more or less desertshiekish love affair.' However, when Iris found she was pregnant Frederick's attentions seemed suddenly less enthusiastic and telling him coincided with more painful mistreatment of her knee at the Rotorua Sanitorium, leaving her even more disabled. Frederick's initial response, that it was impossible that she was pregnant, was made worse by the fact that he appeared suddenly repelled by her disability. A generic dramatisation of a similar scene of male shock at 'pregnancy-news' occurs in her novel Wednesday's Children; Hyde's wider analysis of gender relations (between the wars) in this and other novels interrogates experiences of betrayal and misunderstanding between the sexes.

According to Iris's autobiographical account, her mother summoned Frederick to Wellington to get him to make an offer of marriage but she determined against this solution. Whatever the decision an unmarried pregnancy necessitated leaving town-and Frederick agreed to finance the journey to Sydney and provide a little towards Iris's living expenses. In April she sailed for Sydney; her first accommodation was cheap digs in Surrey Hills where she gained insight into the psychology of poverty, later useful in her novels. She also observed the variety of the city, spent time in the Sydney Public Library and read Nietzsche under 'enormous Moreton Bay figs in Centennial Park'.

There is little information to corroborate any of the differing versions that Hyde tells of the pregnancy. Whether she had planned an adoption; whether the pregnancy was terminated or she miscarried; whether the baby was born prematurely or was full-term, still born or died at birth (in differing accounts it made its appearance somewhere between June and November)-is not clear. However we do know that she moved house to the more comfortable suburb of Stanmore and made a supportive friend, a young nurse. (In The Godwits 
Fly Eliza saves money for a private room at a local nursing home-a lovely old house with jacaranda trees outside the window-but when the time comes her child, a son, dies at birth.) In whichever circumstances, Iris was, at only twenty-years-old, recovering from a secret pregnancy and the death of her baby. Though the baby had no legal identity she gave him the name Christopher Robin Hyde, (in a gesture of defiance using his father's surname-as something for Frederick 'to remember or outface') and from around this time she began taking 'Robin Hyde' as her own writing name-her 'nom de guerre' as she called it. She also dated her commitment to writingparticularly to poetry-as arising at this time. ${ }^{1}$ (The detail with which Hyde described the months in Sydney in later autobiographical writings and in The Godwits Fly suggests that she consistently kept detailed journals as well as writing letters, but, if so, these have not survived.)

By September Nelly Wilkinson had arrived to support her daughter. Mother and daughter were passengers on the Ulimaroa from Sydney to Auckland, arriving 30 November 1926 in Auckland. Iris sent a cable from the ship to Frederick-seeking his emotional support. He, however, had just married. His new wife, Alice Algie was a widow ten years his senior; Iris had known of their relationship and discounted it, but now discovered her mistake. Even her own love-making with Frederick, Iris learnt, had taken place at a house owned by Alice. However, in spite of a sense of betrayal Iris seems to have spent several unhappy weeks in Rotorua being looked after by the newly married couple. From a book of handwritten poems titled 'To Gwen from Iris Xmas 1926' (Gwen Hawthorn) we know that, distressed as she was, she was writing again by Christmas.

Sometime after Christmas 1926 Frederick drove Iris to Hamilton to catch a train to Wellington, but she visited chemist shops to purchase a variety of hypnotics and sedatives and ended the day, not on board the train, but at the hospital. Her mother arrived on the scene once again and supported her through subsequent months of intense mental and physical breakdown, consulting a range of more-or-less sympathetic doctors and caring for her at Northland Road. But she did so without divulging to the rest of the family the precipitating reasons for her daughter's mental distress. Meanwhile Iris (now becoming better known as Robin Hyde) could be seen on the verandah of the family home writing and reading.

\footnotetext{
${ }^{1}$ That the father's name was 'Hyde' was only revealed by Derek Challis in 1998-see Challis, 'The Fate of the Iris Wilkinson (Robin Hyde) Manuscripts' JNZL 16, 1998, 22-32 (published and updated at the New Zealand Electronic Poetry Centre in 2003). It was previously assumed that the name 'Hyde' was the author's invention (as is Derek's name 'Challis') echoing 'Robin Hood' or suggesting 'hiding' and being tough of 'hide'.
} 
A series of poems written at this time describe (and sometimes address) a flirtatious Pierrette (a female Pierot based on friend Gwen); Hyde's longing for a simpler naïve, girlish time in her own past is conveyed in the image of this lovely female clown. The poems are markedly similar both stylistically and in mood to the much admired, late poem sequence, 'Houses by the Sea'. The sensuous 'Rain' (composed by December 1926) appeared in The Bulletin on 26 May 1927, was one of the first to published under the name Robin Hyde:

Rain-murmurings; the wind whines and snuffles, wet

As a poor dog whose lord has ceased to care

For faithful things like dogs. And you, Pierette

With little firelit face and firegold hair

Curled like a kitten in an easy chair

The Pierrette poems are sourced from the Little Saint Christopher manuscript book, which collects Hyde's poems to late 1927. Its dedication:

To the Little Saint Christopher:

The gods of beauty seek in the Spring

From out of the world's white flowering

Some delicate thing to keep ... .

Sleep, child, sleep

is a poem by Rachel Annand Taylor to which Hyde has added a final line, and is the same as that used in The Godwits Fly to describe protagonist Eliza's emotion at her baby's death. In this manuscript book are a number of poems for Robin-one of these tender poems, until recently unpublished, is titled 'To C.R.H' and finishes: 'His little feet will learn to run/on rose-white ways, where by no thorn/May baby-tenderness be torn.' Many of the poems we can now see as having a further not simply rhetorical dimension, coded with their author's secret suffering and sense of belonging to another sadder world.

Though during April 1927 Hyde was regularly sending poems to the Auckland Star, the Sydney Bulletin, the Christchurch Sun and Victoria University College's The Spike she was still confused and unhappy. It was only in May 1927 at Queen Mary Hospital at Hanmer in Canterbury that she began to regain her peace of mind. The freedom and independence from her family and the beauty and resources of the place were significant but so was a sympathetic doctor, who saw that her condition was attributable to a 'history.' Poems such as the tranquil 'The English Trees' date from this time, as does an important and long correspondence with the literary editor of the Christchurch Sun, John Schroder, who wrote complimenting Hyde on her poems. This was to become an important personal and literary friendship; more than 100 letters that Hyde wrote to him from 1927 to 1939 survive. 
In October Hyde left the hospital and, en route to Wellington, visited Christchurch, where she met the editor and others on the Sun newspaper and discussed future writing projects with John Schroder. He was struck by her on first meeting:

She could run away with a suggestion for a literary article and be running back with the finished-and excellent-copy, while another would still be pondering and plodding. She had read little or no Conrad when I told her there was an article, perhaps, in those statuesque, enigmatic women characters of his; but she had read enough in a day or so to write a critical piece that was small, clear lamp of light. (Challis/Rawlinson p. 92 )

Back in Wellington in November 1927 Hyde made the acquaintance of literary editor and journalist Charles Marris, who was to become another valuable mentor, and found employment with the National Tourist Bureau travelling and writing and, when that position finished, freelancing. A poem and her first short story won prizes from the Sun newspaper and her correspondence with Schroder continued; they often discussed books they admired-including $A$ Passage to India and novels by Stella Benson. Unsettling to her new equilibrium though was the news that her first love Harry Sweetman had died more than eighteen months earlier, in February 1926, in Manchester of pneumonia.

During 1928, freelance work was getting harder to find and she could not work for The Dominion having previously resigned a position there. In August there was another loss when best friend Gwen married (Hyde thought for expedience not love) and this added to her sense of being deserted and demoralised. Hyde was, she claimed, not going to marry till 'the age of the wireless hits the kitchen and by then I'll be too old and shrivelled'. She clearly objected to women being cut off from public life but as a woman who wanted everything she also expressed romantic longings, more obliquely, in the love poem 'Tryst' written round this time. September brought her, temporarily, a new position on a different kind of paper: the scandal mongering N.Z. Truth, a position that could have suited someone who had always preferred to write the 'scurrilous paragraph about a public man.' to 'the adulatory one about some welfare women'. An article on spiritualists and healers is interesting for its relationship to her later preoccupation with contacting her own dead lover and baby and is also echoed in Wednesday's Children, but she was finding the unremitting and absolute commitment to journalism difficult, making her feel 'cold and metallic' and when the position was not confirmed looked for a more sympathetic opening. 
The beginning of 1929 saw Hyde visiting the Duffs (Oliver Duff was the associate editor of the Christchurch Press) and by February she was working for the Sun where she remained for a friendly and tranquil three months; in Christchurch she regularly met a group of journalists and writers including poet Jessie Mackay, in whose opinion 'Eileen Duggan and Robin Hyde between them lay the foundations of New Zealand literature'. Why she left this congenial environment is not clear-though her biographer, son Derek Challis, suggests that a brief affair with a fellow journalist, Mac Vincent, may have cooled the relationship with Schroder, or it may have been simply that the offer of a more lucrative position as lady editor on the Wanganui Chronicle was too good to refuse.

In Wanganui Hyde was busy with her column as 'Margot' on the women's page, where she managed to smuggle in interesting articles on writers, being bohemian, women smoking and rural women-some of which were reprinted nationally. She worked long hours and was obliged to attend and write up the provincial city's social events, all of which militated against pursuing her own poetry. Nevertheless, she corresponded frequently with John Schroder planning her first collection, Desolate Star, which was published in November 1929 to enthusiastic reviews, notably from poet Jessie MacKay and journalist Alan Mulgan. The provincial town was impressed by her talent but at the same time kept a sharp eye on her comings and goings, especially what was, in some versions, a very public love affair with a fellow journalist, and as it turned out married man, Lawson Smith. This relationship seems to have been, partly at least, a plan to conceive another child. She wrote to friend Gwen, 'Shall I have him for the father of my Tane? . . . . It is becoming maddeningly necessary to my life to have a child'. Friend and occasional poet Ishbel Veitch and her husband regretted they had introduced Hyde to spiritualism-in séances at their house she more or less seriously attempted to contact her son and Harry-but they knew little of her past or her future plans.

By February 1930, knowing she was once again pregnant and refusing the offer of $£ 20$ for an abortion from the father, Hyde organised a visit to Christchurch on the way to the remote D'Urville Island in the Marlborough Sounds where she proposed to spend her pregnancy. A doctor's note speaking of a heart condition justified absence from the Chronicle and she hoped to survive financially by sending her 'Margot' columns. Time passed in a series of homes and boarding houses in the area of the Sounds and at Picton was, as recounted in A Home in this World, lonely but peaceful and in beautiful surroundings. She wrote articles and letters and read books sent by John Schroder, amongst them recent novels and Montaigne's essays; the poem published in The Conquerors, the remarkable 'Montaigne on the 
Hillside', was drawn from this time. However, her paper, the Wanganui Chronicle, was in financial difficulty and because of that or possibly (as she believed) because of news of her pregnancy, they cancelled her contract in early October so that by the time her baby was born, in Picton on October $29^{\text {th }}$ 1930, her financial situation was precarious. Once more secrecy was involved and she returned to Wellington on the ferry, with the son she had named Derek Arden Challis, concealed in a dress-basket, to look for work. The baby was accommodated temporarily in a city nursing-home she could visit every day and she returned to the house at Northland Road. In A Home in this World she recalled the reception her family-not knowing about Derek-gave her:

In the house, then, I found myself hated: there is no other word. I had deliberately lost a good, profitable job, playing about for six months round about islands and channels. I didn't even look appealing. 'You look about thirty. Fat and coarse. I can hardly believe you're my daughter'.

Unsuccessful attempts to find work were relieved by a summer holiday in Hawkes Bay with Gwen (now Mitcalfe) and her husband and son. Derek was brought along posing as her nephew. The episode seems to have reinforced Hyde's ambivalent relationship with domesticity; a letter to John Schroder reveals, rather elliptically, that she was longing to get away from the stresses of housekeeping and child-caring: 'It's all been rather fun, but very hot and tiring, and I shall be glad to be back in Wellington. Shall put on a new hat, and some eau de cologne on my hanky, and walk leisurely through the streets thanking Heaven I am not a hot and harassed Hawke's Bay housewife'. However, Hawkes Bay housewife or independent woman journalist was not Hyde's immediate dilemma, rather she had to plan care for her child so she could resume her career. It was her friend Gwen who introduced her to a Palmerston North family who fostered Derek so that, when shortly after her return to Wellington a telegram arrived offering, most fortuitously, a position as 'Lady Editor' on a small Auckland weekly the New Zealand Observer, she could promptly accept the $£ 4$ a week offer. She arrived in Auckland in late January 1931 - this city was to be her home for the next seven years

The Observer was initially an exciting challenge, an established but dwindling newspaper owned by an elderly cartoonist, it had recently appointed a new young editor, J. G. MacLean, who had established new book review and leader pages and who-when the management proposed a lady editor to contribute to social and fashion pages and attract women readers-suggested Hyde's appointment. Multiple roles ensued, lady editor under the name Iris Wilkinson, book and film page editor, special article writer under the name 
Robin Hyde, social page columnist under the name Jennifer Larch, and so on. Her first feature article, on 'pungent' conditions at the main Auckland gaol, Mt Eden, did so well in getting the paper talked about that 'the prison authorities spent hours hunting through the files for a convict named Robin Hyde!' In the Bookman page of the same issue (5 March 1931) she wrote a rebuttal of D'Arcy Cresswell's review of Kowhai Gold, an anthology edited by Quentin Pope, exposing the literary back story (Cresswell's controversy with the editor about his own poems). The Observer gave Hyde a new prominence-a position from which to air her views on both literary and social matters. But there was more, as a social columnist in 'tinsel town' she was also required to look the part in a new dress, 'something classical in black satin,' and a white rabbit coat.' that 'a furrier who stayed at that the same boarding house (in Princes Street) used to lend'. For the next few years her workload was extraordinary and her output phenomenal.

The private hotel or boarding house, Burwood, where she stayed (until at least mid-1932) was in Princes Street near the university; she had first known it as Harry Sweetman's accommodation when she had visited him at Easter 1924. It was here also that she got to know Joe, a Queen Street pharmacist, who became her escort to dinners, theatre and other outings and significantly supplied her with un-prescribed narcotics that alleviated immediate physical and mental pain but eventually contributed to her mental and physical breakdown in 1933. During 1931 and 1932 articles by Hyde appeared in The Observer on 'the drug problem' in which she half discloses her own predicament. Her analysis: 'The crushing wheels of the twentieth centuryoverstrain, overwork, financial worry, noise, bustle-have brought about the reign of narcotic poisons.' And then more specifically of morphine: 'The addict usually gets the habit from being given hypodermic injections in hospital, whilst suffering from some acutely painful, complaint' (The Veronal Menace, 28 July 1932).

Another anxiety was her son, Derek's, welfare; in the Christmas holidays of 1931/2 she visited him at his foster home in Palmerston North, the Rattan's 'little smoky house', as she described it, and a few weeks later asked Mrs Rattan to bring the baby north by train. For a few weeks Derek boarded with his mother and another young woman in her city accommodation. In this fun time Iris recalled being happy and not 'drugging,' but the situation was not tenable-she needed to work to support him. A foster home was found in the suburb of Mt Albert with an older couple and their elderly uncle, where she was able to visit weekly. The Hutsons had a tradition of social activism and were a solid if impecunious family who proved an ongoing support to Iris as well as to her son. 
As in the last months of her life (during 1939 in London) Hyde's mood intensified with the heightened political situation. During 1932 there was increasing social unrest in Auckland and throughout the country, demonstrations, political meetings at the old London theatre, and political discussions at Kealy's, the Shortland St bookshop and library. Hyde paid close attention to all this, questioned political speakers, joined discussions and gained a reputation as the lady editor who would represent the underdog. Communist activist Jim Edwards recalled her concerned investigation into his trial when he was accused of being responsible for the Queen Street riots-a meeting of desperate unemployed men who overflowed out of the Auckland town hall and began breaking shop windows and looting. But she was also unwell, tired, using drugs again and struggling financially.

During 1933 Hyde had joined the Social Credit Party and had the opportunity to air her views in speeches on, amongst other topics, the hardship of women who, when working, contributed to an unemployment fund but, when unemployed, were unable to receive any social security benefits themselves. In the last week of May, while she was off work with the flu, she was reported in The Herald as speaking on this subject at a meeting in the town hall, a fact that may have exacerbated an already tense situation at The Observer where she was having many arguments with her young employer, MacLean, and her drug use must have been becoming obvious. On the $1^{\text {st }}$ of June she was given notice from the paper and the next day attempted suicide by jumping off the wharf at the bottom of Queen Street. Rescued, she was arrested (suicide was illegal) and taken to the cells for women delirium tremens patients at Auckland Hospital to await a trial.

This extraordinary catastrophe was also a reprieve from financial responsibilities and became almost immediately a kind of creative opportunity: her plight drew friends and professional support, and in the hospital cell she began, for the first time in three years, writing poems again. After being remanded in court she insisted on returning to the hospital but was eventually persuaded (by Dr Buchanan the medical superintendent) to transfer as a voluntary patient to the neuropathic ward (The Lodge) at Auckland Mental Hospital at Avondale. The Lodge was a lovely commodious house that had been built for one of the first superintendents and accommodated those middle-class women considered borderline cases. Bed rest and domestic activities were the main treatment-and patients were encouraged to gain 'insight' into their condition. Hyde was certainly deeply disturbed; her condition included sleeplessness, hearing voices and bouts of fearfulness and weeping but would probably now not be characterised as schizophrenic as it was then.

Days after admission, Hyde's poems began to appear in newspapers ('She' in the Auckland Star on the $24^{\text {th }}$ of June, 'Seaborn' on the $8^{\text {th }}$ of July). As at 
Hanmer, the isolation and care of the hospital allowed her peace to write. However, before she could in the eyes of her doctors, participate in recovery, there were incidents of smuggled drugs, removal to the main block, the Wolfe Home, and F 7 where seriously disturbed patients were locked up, and selfdischarge from the hospital. Trying to pretend that her mental condition was resolved, she visited family and friends and took a commission from the Railways Magazine, travelling up by service car to write on the wonders of the North. However, this was a brief and unstable interim. It was at this time that Hyde first met the child poet Gloria Rawlinson and her proud mother Rosalie-who were to become important figures in her life and in keeping her memory alive after her death.

In December, the day after appearing at the Magistrate's Court in Auckland on the charge of attempting suicide, Hyde again collapsed in a public place. This time she had an idea where to go: she asked to be taken back as a voluntary boarder to The Lodge and the care of Dr Gilbert Tothill. Her brief meeting with him had convinced her that he was someone she could trust to help her; he was to be her main psychiatrist over the years of her residence at The Lodge. He encouraged her to revisit the events in her life that preceded her breakdown and to face her demons. However, her fears of poverty, homelessness and not being able to support a child were not dissimilar from those that had brought other patients to the Lodge and made it in that sense a place of genuine asylum. Works that can be identified as composed at this time are a series of plays, one of which, Eurydice, she sent to the young poet Gloria Rawlinson describing it as a 'written when I was pretty sick,' poems, and some short stories. The poems (many later published in The Conquerors) she sent to magazines and newspapers seeking some money for herself and her son; they share themes with unpublished material, childbirth, lost children, dislocation and near death, the search for alternative worlds. From her bedroom she wrote:

I should like to die in this room-

It looks towards the West.

Outside, the great bronze sickle of the dusk

Mows the red poppies of the sunset clouds.

Washed up as she was in this new place, 'bowed like a reed' beneath the events of her previous life, love seemed to belong to other worlds; she inscribed herself as like other otherworldly prisoners and exiles, Eurydice, Persephone, or Elaine of Astolat, even Ouida's Folle-Farine. Yet she also shows in the story 'Lighted Windows' written at this time that she (or her protagonists) had always loved to play at other roles, other lives. If the ability 
to switch roles and speak for those 'cut off from the living' was at this point in Hyde's life a kind of instability, it also marks her as a bohemian defending courageous nonconformists and exposing pretensions; a feminist both intellectual (smuggling serious comment into women's pages) and empathetic (showing compassion for the difficulties of women's roles, especially motherhood in poverty and isolation); and as a creative writer, a weaver of fictions and stories, narratives and poems that could save her.

Hyde's doctors encouraged her to turn her attention away from a career in newspaper journalism with all its daily stresses (and now very probably rejection-John Schroder rejected her application to be The Sun's children's page editor) and to develop her talents as a prose writer and poet. Dr Tothill suggested in what must have been one of their first consultations that she should write an autobiography; by the end of February 1934 under a regime of writing in the mornings and gardening in the afternoons it was complete. This manuscript, although not published, signals the beginning of Hyde's attempt to become a professional writer. It is conceived in book form interleaving prose and poems, a practice that she continued in the draft of Journalese (1934) a humorous, behind-the-scenes account of twelve years in journalism that was carefully checked with her lawyer before being accepted for publication in September.

Hyde occupied the only single room at The Lodge and eventually also had a study in an attic situated conveniently just above it. Literary mentors such as Charles Marris, editor of the annual Best Poems and Art in New Zealand, visited her here. Marris helping her select a manuscript of poems sent off in May to an English agent A. P. Watt and accepted by Macmillan on the recommendation of poet Lawrence Binyon who commented: 'Mr Hyde is rather lavish with words of colour . . . . But there is vein of true poetry in this collection and he ought to have a future.' The poems were published as The Conquerors (1935) in a contemporary poets series.

By June 1934, now allowed three trips a week to town and an 8pm curfew, she began to make regular visits to The Observer offices and the Auckland Public Library. At the library she researched the life of $19^{\text {th }}$ century utopian Baron de Thierry who had wanted to create an independent 'kingdom' in the North of New Zealand (the Hokianga) for her first novel Check to Your King. Friends noticed an astonishing transformation in her energy and mood: the novel was complete by December, by which time she was also writing regularly freelance (mainly reviews) for The Observer-expenses for herself and her son Derek's fostering were still very pressing. In early 1935 she began another autobiographical work also dedicated and often addressed to her doctor, known as the '1935 Journal' this is a diary in which (amongst other things) she describes the detail of her environment, the other patients, ideas 
of sublimation and transference and her own ideas for writing exercises as treatment for the mentally ill. This document is full of humour, liveliness and self-reflection and is altogether lighter in mood than her 1934 autobiographical manuscript.

Hyde's determination to make her living and reputation as a serious writer intensified in the years 1935 and 1936. In this time she produced some 120 new poems; completed and published Check to Your King and Passport to Hell (a war novel); completed two drafts of The Godwits Fly and drafts of Wednesday's Children as well as two other unpublished novels; and published short stories and articles in the Bulletin, the Christchurch Press, Art in New Zealand, the New Zealand Railways Magazine and other papers and periodicals, also submitting many of these for prizes and awards. A controversy over the accuracy of the details of Douglas Stark's life, the real soldier and exotic figure on whom Passport to Hell was based, dogged her, but was typical of the difficulties of writing fiction in the small provincial society. In Britain where the novel was published it received enthusiastic reviews in spite of the fact there was little appetite for war books at the time and sales there meant there were few remaining copies to be shipped to New Zealand. Hyde described the novel as an 'illustration of Walt Whitmans' line: 'There is to me something profoundly affecting in large masses of men following the lead of those who do not believe in man."'

At the same time she was hard at work on a very different project the 'Sort of portrait of a dreamland as seen by a young female with not much talent for living' that was to become Wednesday's Children. In this novel the main character, Wednesday, is caught between down to earth misery and escape into the incredible and fantastic-an escape similar to that Hyde's doctors counselled her against. Both these novels and Nor the Years Condemn (a sequel to Passport to Hell) sought to paint a full picture of the identity crisis and adversarial relations between men and women that Hyde saw as the consequence of the Great War. In Avondale Asylum alongside wards full of returned soldiers and at the Lodge amongst disturbed and homeless women suffering the consequences of domestic breakdown or lack of family support, she was writing novels that produced a narrative explanation and historical context for this mental distress. Another theme was child rearing: not much good or practiced at motherhood herself, she was filled with compassion for its difficulties-especially under conditions of poverty or isolation

1936-1937 was a period of transition for Hyde marked by a geographical and emotional shift away from the Lodge and towards her decision to pursue her career in England. Seeking independence and more quiet to write she began to take leave weekends away from The Lodge at a bach (holiday house) belonging to friends and neighbours of poet D'Arcy Cresswell's on 
Auckland's North Shore at Castor Bay. Seeking more public profile, in April, the same month in which Passport to Hell was published, she delivered an impassioned speech at an Auckland Authors' Week (1936) asking the audience, and the country, not only to provide more money to support writers but also to give writers their lives-'We want that part of you which is unexpressed and put aside as daydreaming.' One of the organisers of the Auckland Authors' Week was Hyde's old acquaintance, now cabinet minister and novelist John A. Lee; from this time on they developed a correspondence. Whereas in her letters to John Schroder, Hyde often sought reassurance and literary guidance, the epistolary relationship with Lee was from the start more equal-as they compared and contrasted their writing intentions. Towards the end of her life in June 1939 she was to write to him that they were allied in their anticonformity: 'What makes us so grubby in the eyes of the respectable is wanting so much ... . [and] getting so much more than they say we can.'

A further acknowledgment of her new status as a writer came in September 1936 with an invitation from Downie Stewart the chief librarian at the Hocken Library in Dunedin to travel south to research the papers of another historical personage Edward Markham. This trip away from Auckland was made with the permission of her psychiatrist and with the confidence that she had a safe haven to return to. However, while her stay with the Stewarts did allow her to begin re-drafting her bio-fictional novel The Godwits Fly (with which she had been having some problems) the plan to work on the Markham papers ran into trouble and the library withdrew access perhaps because of the continued dispute about the accuracy of Hyde's fact-based Passport. Only the poem 'Arangi Ma' remains as record of this project.

A diverse journey followed: to Stewart Island, Queenstown, Christchurch, The West Coast, a holiday in Nelson and Blenheim with her mother, culminating in an aeroplane flight to Wellington. The breadth of this experience added to her sense of her self as a New Zealander and inspired many new poems. Michele Leggott summarises: 'Ethnicity, gender relations, revisionist theology, invasions personal and historical, remembered or imagined, enter the poems as part of an increasingly self-conscious search for the "young knowledge" that will fit the person, the place and the generation she writes from and for.'

After Christmas, spent with family in Wellington (where the poem 'White Seat' was composed, Hyde returned to The Lodge in the new year of 1937. But the place was now significantly different for her: on the $1^{\text {st }}$ of January 1937 Gilbert Tothill had taken up a position as Medical Superintendent at Tokanui Mental Hospital in the Waikato. This career advancement for Tothill was bad news for Hyde who had, as she put it, 'lived under her doctor's eye' ever since her 'bad crash'. She had for the past 4 years consulted Tothill 
constantly on personal, professional and literary matters, not only when she was at her most distressed and frightened but increasingly seeking his guidance as her health improved: for example consulting him when Douglas Stark ('Starkie') became over-attached to her; asking him whether or not she should accept writing commissions; getting him to read manuscripts and dedicating works to him. The trip to the South Island had been made with the confidence that The Lodge was sanctuary to which she could at anytime return. Tothill's unheralded acceptance of this new position was to precipitate her also into a sudden departure. But before that she arranged to rent baches for three weeks at the deep and beautiful Whangaroa Harbour on the east coast up North. Here she finally completed the typescript of her most reworked novel The Godwits Fly the semi-autobiographical work she had first begun in March 1935, and which had gone through several different versions as she struggled to tell a truth open or equivalent enough to her own experience. This novel is the most directly inspired by the narrative therapy that her psychiatrist prescribed. Two years later when the novel was published in England it was dedicated to:

\author{
'Dr G.M.Tothill \\ This imperfect part of truth \\ Robin Hyde (Iris Wilkinson) \\ April 1939, England'
}

In early March, back at The Lodge, Hyde did not like the new psychiatrist assigned to her and after a disagreement with him and other doctors discharged herself and rented accommodation in Waitararua in the Waitakere ranges near Auckland where she proceeded to write the autobiographical fragment posthumously published as A Home in this World; this sequence follows on from the events that closed Godwits divulging the difficult story of her second pregnancy and birth of Derek; here she also most probably wrote the traumatic 'A Night of Hell' telling of over- dosing on opiates. A move to a more permanent address (another bach) back at Castor Bay (later superseded by another at Milford) saw her writing the long prophetic poem Nadath and beginning on the first draft of the Passport sequel, Nor the Years Condemn. This year also saw poems collection Persephone and novel Wednesday's Children accepted and published by Hurst \& Blackett, articles published in the Observer about the possible eviction of Maori from Orakei in Auckland, and early drafts of the poem sequence 'Houses by the Sea' composed while on a farewell visit, in December, to family in Wellington.

With so much achievement and success Hyde was now ready to try her hand overseas. She had written about godwits, the birds that fly every year 
from the Southern Hemisphere back to Siberia and about her mother's 'England hunger', but for her this journey was most imperatively a pragmatic attempt to extend her reputation as a writer and win a wider audience for her work. She hoped too to make her fortune or at least increase her income and to return able to afford accommodation and livelihood for herself and her growing son (now 7 years-old); she farewelled him with this promise.

The day before her thirty-second birthday, $18^{\text {th }}$ January 1938 , Hyde set sail on the Awatea for Sydney and from there for Hong Kong on the Changte sailing via Brisbane, Cairns, Thursday Island and Manila keeping continuous diaries and notes which were to come in handy for composition of her travel story (which became a war story) written when she got to England. The entries that remain were written in a notebook given her by Ron Holloway of the Unicorn Press. En route she wrote a poetic essay 'The Word' that continued the utopian conversations of Nadath. Her plan was to take a ship to Kobe in Japan and another ship to connect with the Siberian Railway to Europe and England. However, both the international situation and Hyde's enthusiasms intervened. In Hong Kong the passage to Kobe (she had wanted to witness Japanese culture and its courtly traditions) was delayed and Hyde spent a week in Hong Kong. This gigantic, crowded city full of refugees from the Sino-Japanese War was her first experience of a non-English culture. It inspired her to see more of China and gather material for a book. She was well aware of the international situation as regards China and Japan (the call for intervention against Japan's invasion of China and dispute about the inaction of the League of Nations) but was extremely keen to travel into China and behind enemy lines, looking, it seems, to experience first-hand oppression in the guise of war. On the $17^{\text {th }}$ of February Hyde sailed for Shanghai; as she left she prudently posted most of her literary papers ahead of her to her agent A. P. Watt in London.

The Shanghai she arrived in had been occupied by Japanese soldiers since November 1937 following months of Chinese resistance and street fighting and, like Hong Kong, was home to thousand of refugees. Not far away was the ancient city of Nanking that had suffered in December 1937 a terrible siege during which the Japanese soldiers raped thousands of women, and citizens of all ages were brutalised, tortured and massacred. Hyde was anxious to understand the political and humanitarian situation and on her first afternoon in Shanghai went on an expensive organised 'tour' of the battlefields. She had thought of finding employment with a local newspaper but had not understood the disruption and confusion the occupation of the city had imposed on newspapers. Her naivety and humorous interest in the exotic at this difficult time clearly irritated a number of people she met, including fellow New Zealander, the socialist and teacher, Rewi Alley (later famous as 
one of the very few Europeans allowed to stay on in China after the revolution). Alley was, nevertheless, very helpful: he introduced her to two women Chinese welfare workers who showed her around the city, visiting parks, markets devastated areas, children's homes, factories, hospitals and refugee camps, and also to Anna Wong the German and feminist wife of Wong Pei Hei, a German-educated soldier who was fighting with the Chinese army in the north, with whom she stayed in a Chinese styled house in the French concession.

From here she wrote letters, articles for New Zealand magazines Woman Today and the Mirror, as well as for the Far Eastern Mirror and China Critic, and began on many of the 'China poems' later collected in Houses By the Sea. Among these poems is the much anthologised 'What is it Makes the Stranger?'-a poem that shows that the need to cross/fuse discourses is most urgently understood and communicated by those who, like Hyde, have 'been called stranger' in their own land

Shaking the sweet-bitter waters within my mind, It seemed to me, all seas fuse and intermarry: Under the seas, all lands knit fibre, interlock.

On a highway ancient as China's

What are a few miles more, to the ends of the earth? Is another lantern too heavy, to light up, showing the face Of farers and wayfarers, stumbling the while they go, Since the world has called them stranger?

When the pro-Chinese fortnightly the Far Eastern Mirror offered Hyde a commission to travel to Canton and possibly further north to act as a roving reporter, she returned to Hong Kong on the $15^{\text {th }}$ of March determined to get a visa. In the few days spent in Hong Kong she briefly met up with fellow New Zealand writer and scholar, James Bertram, who had himself just returned from a five-month journey in North China, spending a day with him at Macao. Like Bertram, she wanted to write a book of her journey and this was firmly in her mind when she left for Canton.

From the 'completely Chinese city of the interior' that she was promised she was indeed able to travel on to Hankow, where the Chinese army driven North from Naking was making a stand against the invaders, and from there closer to the front line to Hsuchow. She arrived at Hsuchow on the $1^{\text {st }}$ of May 1938 where she stayed at American Mission Hospitals. On the $10^{\text {th }}$ of May aerial bombardment of the city began and shortly after the railway line was cut, so that she was unable to leave Hsuchow before it was occupied on the $19^{\text {th }}$. Nevertheless she was writing to her mother at this time about the poems she was working on: 'a longish series about Wellington, from Island Bay to 
your sewing-machine, and a slight one called 'Fragments from Two Countries' ... They're in Hankow, with a suitcase and my typewriter'.

In Journey from New Zealand, also drafted at this time, the recollection of her home city is coloured by the Chinese ones she has stayed in:

Ours was a city, like any city,

But with more perhaps of sea and cloud, not long loved.

November tar, ripening, blackened our sandals.

Our city had doorways too many shut.

Morning and evening, facing the rampant crimson brutes of the light,

Nobody had the beautiful strength to decree

'Leave your doors open, morning and evening:

Leave your doors wide to the stranger.'

In 1937, looking from New Zealand, she had been in the business of prophecy, writing the long poem 'Nadath' and like many of her contemporaries haunted by the threat of yet another world conflict. In China her poems celebrated fragments and detail, not only in the search for personal healingthe close observation of one's environment to rectify the neurotic obsession with personal ills that she recommended in her '1935 Journal'-but also as a way of unifying different worlds. And we may also see here the literary influence of Ezra Pound's versions of Arthur Waley's Chinese translations.

On the $19^{\text {th }}$ of May in a letter to her young son she wrote that she was proud of being the only foreign woman journalist to 'get as far forward' because our 'country is right at the tail-end of the map and we need all the restlessness and ambition we can get'. In a letter to Dr Tothill round this time, however, she expressed a different motivation: 'After Hankow I'll know if I'm more of a baby than anyone else and if not that will be because of your help'. This extraordinary personal test she set herself was too much for her, but not more so probably than it would have been for anyone else. On the $16^{\text {th }}$ of June Hyde managed to escape from Hsuchow by walking along the railway line; after a frightening series of events including an assault (all of which she later described in Dragon Rampant) she was taken to the British Consulate in Tsing Tao by Japanese authorities. Rest time here, a journey to Shanghai and then back to Hong Kong finally saw her in hospital and diagnosed with the tropical disease sprue. Hospitalised again briefly in Singapore, she arrived at Southampton on the $18^{\text {th }}$ of September on the Johan van Oldenbarnevelt. She was a godwit come 'home' but she was very sick and it was an inauspicious time to arrive in Europe.

Needing an inexpensive place to live, Hyde soon found the English equivalent of a bach, a caravan in Kent. It was primitive and often depressing 
accommodation, especially as the weather became colder, but she was busy with her 'Chinese book.' Dr Buchanan, the Superintendent of Avondale Hospital who had always been a good friend visited her here and was concerned at the conditions. Also in November she received the first copies of her novel The Godwits, but Wednesday's Children was selling poorly and money was tight. And poverty-not enough money for heating or sufficient food-was far worse in England than in China where there had been a certain fraternity. She particularly needed cash to buy two medicines, one a sleeping draught without which she suffered constant insomnia. In mid-December she made a move to London, to the same hotel/boarding house in Bloomsbury where James Bertram was living. In the days following Christmas 1939 Bertram was increasingly worried about her physical health and managed to get her admitted to Middlesex Hospital. However, in spite of many letters and some visitors, she discharged herself. The China book she called 'Accepting Summer'-re-named (oddly) Dragon Rampant by her publisher-was finished but encountering some problems. Hurst \& Blackett were worried about its proChinese stance but did finally accept it in January. Some of the advantages of being in London were becoming apparent as Hyde met more people and became involved in various political and cultural groups-the China Crisis, the United Front and the Left Book Club. However, another spell of ill health saw her back in hospital, this time at the specialist Hospital for Tropical Diseases in London where she remained for a month. It was while here that she was first contacted by a theatrical couple wishing to adapt her novel Wednesday's Children for the stage. She was also visited by New Zealand poet and editor, Charles Brasch. Bertram, who was planning to leave London, particularly asked Brasch to look out for Hyde and the two became friends.

In March (on leave from hospital) Hyde dined with James Bertram in a French restaurant in Soho using a gift of cash in a letter from John A. Lee; they discussed China writing. (In a letter round the same time she speaks of being disappointed by Christopher Isherwood's travel diary, though she had also met and liked him.) She described Dragon Rampant as: 'secondarily a war book, primarily a book about people-not Consular book-or maybe a war book reflected through people.' At around the same time in a letter to Lee she thanks him for his praise of Godwits and explains that she thinks it is because she is indeed challenging conformist morality that it was receiving some negative reaction: 'much of the really unfair criticism . . . is based on sexual grounds. And they are quite right to attack, because though they are mostly too dumb to know it clearly, I'm attacking - and have, and shall, with luck. So though I do get hurt and squeal I haven't a real claim to squeal'.

Hyde was now very depressed at the worsening international situation and hoping that her own country would stay out of the conflict. She was also very 
unsure what to do herself, whether to stay or go-many fellow New Zealanders were leaving England-and though at times she regained her health and was revising and writing new poems and articles it was hard to survive financially and the way forward was very unclear. The fine, late poem 'Arachne' was probably first drafted at this time in hospital.

After hospital-not cured, but improved in health following transfusions and a special diet-Hyde was invited to stay at Bishop's Barn, a country cottage in Wiltshire that Charles Brasch had been loaned for his last three months in England. She also stayed for some weeks at the Charlotte Street flat belonging to the Cravics - the couple with who she was in negotiation about the dramatisation of Wednesday's Children. The negotiations with the Cravics did not go smoothly, and although she was pleased to be at a distance from the literary in-fights and slights of her own small country, England had the ability to generate another kind of despair: she felt more marked and excluded in England by her poverty than in New Zealand. With her left-wing connections and the publicity surrounding Dragon Rampant, which was a noted book when it was published in July, she did begin to meet the people who might have lifted her out of these constraints. There were things to look forward to: she was nominated as a representative to a P.E.N conference in Stockholm in September. The China Campaign Committee was organised from Victor Gollancz's Left Book Club and here Hyde met, among others, Sylvia Pankhurst. Famous as a suffragette, Pankhurst, following the Italian invasion of Ethiopia in 1936, had begun a newspaper The New Times and Ethiopia News as well as a bookshop that ran a lecture series to which Hyde contributed on August the $10^{\text {th }}$. Following the lecture, Sylvia entertained Hyde at her house and, seeing her fragility, recommended an osteopath and made plans for a friend of hers to accommodate Hyde in her pleasant house.

Hyde now was very anxious. The imperative to live in the present that was part of the mental health 'cure' she had achieved at The Lodge was very difficult given the circumstances. The few New Zealand friends that were left in London were sometimes wary of her extremes of emotion. Notwithstanding the comments in the Challis biography, it seems fairly clear she was returning to the self-harming and drug-taking habits of the past (see Challis/Rawlinson, p. 714). A depressing little attic room in Notting Hill that she had moved to when she left Charlotte Street at the end of May did not help matters. She had also begun to use the new amphetamine benzedrine which at the time was regarded as miracle drug for clearing the mind and relieving anxiety. There was next to no awareness of its toxicity in high doses and its other effect of increasing depression or paranoia. It was with this drug, perhaps combined with gas from her stove, that she killed herself on August $23^{\text {rd }} 1939$. In the days before her death Hyde had been visited by the New Zealand High 
Commissioner who offered to help with her fare home to New Zealand, in an interview at the inquest he reported that she had said she didn't want to go home, she wanted to go back to China. China with its 'ancient highway' was a place where she had shown in her writing that she felt painful and exclusive differences were diffused; she always styled the way she wanted to live her life with her poetic vision.

Critical reception of Hyde's work has waxed and waned: her growing reputation in New Zealand and Australia as poet and novelist was cut off by her death. Although most of her work was published in the United Kingdom, with Dragon Rampant achieving bestseller status and receiving positive reviews in the Times Literary Supplement and other London papers in the July before she died, she remained virtually unknown there. Her dream of making an international reputation was thwarted not only by her own ill health but also by the worsening international situation-as Europe edged towards war, attention was elsewhere. Notices and obituaries in the New York Times and in the London paper the New Times and Ethiopia News and many in New Zealand papers, proclaimed the loss of a talented young writer but little or no attention ensued following her death. It was not until 1952 that Gloria Rawlinson's edition of Houses by the Sea and Other Poems appeared and, although this rich collection was published by Caxton Press and editor Denis Glover, there was a general hostility amongst the new generation of poets to what was seen as Rawlinson's sentimental and feminine presentation of Hyde's work. Hyde's death, perhaps coinciding with so many other wartime deaths, rather than making her a tragic figure seemed at first to have made her a rather tiresome one.

Until the 1980s Hyde was valued most for the social realism of The Godwits Fly which was continuously in print in New Zealand classics series, and for the celebration of New Zealand identity in her much anthologised 'Houses by the Sea' and longer poems written about New Zealand in China. This assessment was echoed but negatively qualified by Allen Curnow in his selections and introductions to the 1945, 1951 and 1960 Book[s] of New Zealand Verse: he suggested in the 1945 introduction that her best work was created almost by mistake and that Hyde was an impulsive writer 'who did her best unawares' and did not substantially alter this view in the similarly patronising tone of the 1960 Penguin. Even Gloria Rawlinson, with access to much unpublished material, tended to replicate a nationalist view. In the 1980s attitudes to Hyde's work began to change, a feminist perspective foregrounded her career as a journalist, her fierce independence and her previously unknown or considered-irrelevant situation as twice over an unmarried mother. Her commentary on the conformist society of the $1920 \mathrm{~s}$ and 1930s was now seen to be manifest in her interesting and unconventional 
life. Quarrels over her representation and her degree of agency ensued. A 1984 telefeature Iris, about Hyde's life, directed by Tony Isaac, one of the first on video, was criticised as sentimental and appropriative by Linda Hardy, Phillida Bunkle and Jackie Matthews in articles in Broadsheet magazine. The most recent critical work on Hyde has made available much new information and primary material. Hyde's son Derek Challis has drawn on his own collection to update Gloria Rawlinson's biography, begun in the 1950s and abandoned by her in the 1970s. A very comprehensive collection of poems has been edited and introduced by Michele Leggott. A doctoral thesis by Lisa Docherty collects correspondences with John Schroder, John A. Lee, Downie Stewart and Pat Lawlor. Forthcoming is a composite of Hyde's autobiographical works as well as a book of essays on the writer and her work. Leggott's work includes essays and editions of two long poems. All these and the poetry collection Young Knowledge imbue Hyde's work with new understanding of the events of her life and vivify their emotional intensity with special attention to how Hyde codes her love for her doctor, Gilbert Tothill. The Challis/Rawlinson biography is valuable for bringing new material to light but is less strenuous interpretively being extremely detailed and allinclusive. Scholarship on Hyde continues with many new contexts such as mental health and the Pacific theatre of war commanding attention.

\section{LINKS}

New Zealand Electronic Poetry Centre

New Zealand Literature File

New Zealand Book Council

Dictionary of New Zealand Biography

\section{BIBLIOGRAPHY}

\section{BOOKS}

The Desolate Star and Other Poems. Christchurch: Whitcombe \& Tombs, 1929.

Journalese. Auckland: National Printing, 1934.

The Conquerors and Other Poems. Macmillan's Contemporary Poets. London: Macmillan, 1935.

Check to Your King. London: Hurst \& Blackett, 1936. Auckland: Penguin, 1975, 1987.

Passport to Hell. London: Hurst \& Blackett, 1936.

Persephone in Winter: Poems. London: Hurst \& Blackett, 1937.

Wednesdays Children. London: Hurst \& Blackett, 1937.

The Godwits Fly. London: Hurst \& Blackett. 1938

Nor the Years Condemn. London: Hurst \& Blackett, 1938. 
Dragon Rampant. London: Hurst \& Blackett, 1939.

\section{EDITIONS AND COLLECTIONS}

Houses by the Sea and the Later Poems of Robin Hyde. Ed. and intro. Gloria Rawlinson. Christchurch: Caxton, 1952.

The Godwits Fly. London: Hurst \& Blackett. 1938. Ed. and intro. Gloria Rawlinson. Auckland: Auckland University Press, 1970.

A Home in this World. Intro. Derek Challis. Auckland: Longman Paul, 1984.

Dragon Rampant. London: Hurst \& Blackett. 1939. Intro. Derek Challis. Critical note. Linda Hardy. Auckland: New Women's Press, 1984

Selected Poems, Ed and intro Lydia Wevers. Auckland: Oxford University Press, 1984.

Passport to Hell. London: Hurst \& Blackett, 1936. Ed. and intro. D. I. B Smith. Auckland: Auckland University Press, 1986.

Nor the Years Condemn. London: Hurst \& Blackett, 1938. Intro. Phillida Bunkle, Linda Hardy and Jacqueline Matthews. Auckland: New Women's P, 1986. Dunedin: Otago University Press, 1995.

Wednesday's Children. Preface and afterword Susan Ash. Auckland: New Women's Press, 1989.

Disputed Ground: Robin Hyde, Journalist. Ed. Gillian Boddy and Jacqueline Matthews. Wellington: Victoria University Press,1991.

The Book of Nadath. Ed. and intro. Michele Leggott. Auckland: Auckland University Press, 1999.

The Godwits Fly. Ed. Patrick Sandbrook. Auckland: Auckland University Press, 2001.

Young Knowledge: The Poems of Robin Hyde. Ed. Michele Leggott. Auckland: Auckland University Press, 2003.

\section{SELECTED CRITICISM}

Rawlinson, Gloria. 'Robin Hyde and The Godwits Fly.' In: Critical Essays on the New Zealand Novel. Edited by C. Hankin. Auckland: Heinemann Educational Books, 1976.

Bunkle, Phyllida, Jackie Matthews and Linda Hardy. 'Who is the Real Robin Hyde?' Broadsheet, 126 (Jan/Feb 1985): 22-26.

Price, Chris. 'The Childish Empire and the Empire of Children: Colonial and Alternative Dominions in Robin Hyde's Check to Your King and Wednesday's Children.' In: Opening the Book: New Essays on New Zealand Writing. Edited by Mark Williams and Michele Leggott. Auckland: Auckland University Press, 1995.

Leggott, Michele. 'Opening the Archive: Robin Hyde; Eileen Duggan and the Persistence of Record.' Hecate 20:2 (1994): 193-216; reprinted in Opening the Book: New Essays on New Zealand Writing. Eds. Williams and Leggott. Auckland: Auckland University Press, 1995.

Murray, Stuart. 'Robin Hyde: Not for Ordinary Purposes.' In: Never a Soul at Home: New Zealand Literary Nationalism and the 1930s. Wellington: Victoria University Press, 1998.

Paul, Mary. Her Side of the Story : Readings of Mander, Mansfield \& Hyde. Dunedin: University of Otago Press, 1999.

Challis, D. A., and Gloria Rawlinson. The Book of Iris: A Biography of Robin Hyde. Auckland: Auckland University Press, 2002. 
Evans, Patrick. 'Robin Hyde and the Postcolonial Sublime.' Landfall, 204 (Nov 2002): 38-45.

Edmond-Paul, Mary. Lighted Windows: Critical essays on Robin Hyde'. Forthcoming mid-2008 Otago University Press. 